\title{
A NEW MIDDLE CLASS ON OLD ACADEMIC GROUNDS: LAW STUDENTS OF THE CLUJ UNIVERSITY IN THE 1930s
}

\author{
ZOLTÁN PÁLFFY 1
}

\begin{abstract}
One of the main tasks of universities of Central and Eastern Europe is that of forming loyal and reliable citizens ready to fill in the ranks of public service. Educational credentials make for social elevation into the ranks of this peculiarly state-dependent middle class. Law students make the relative majority of those engaged in higher learning in the region all through the first half of the 20th century. Where and when there is an acute need for a new middle class under a new state sovereignty, it is law studies that are notoriously perceived as meant to producing the bulk of it. The University of Cluj in the inter-war period is a case in point. The paper shall put forward a selection of data (from an ample statistical survey of elite formation via upper-level education in Central Europe) on this segment of the student population in the 1930s, setting it against a dramatically changed background (the general one and the local one, as traced in secondary sources): how do Romanians cope with the task of producing this new middle class on old grounds, and what are the unwanted side-effects of such state-related social emancipation mechanisms? And how non-Romanians behave in the new situation?
\end{abstract}

Keywords: elite formation, higher learning, enrolment patterns, nation-building, nationalism, inter-ethnic competition, Transylvanian social history

\section{Introduction: the general framework}

The late $19^{\text {th }}$ and early $20^{\text {th }}$ centuries can be generally described, particularly in Western Europe, in terms of the rise of the modern educational system ${ }^{2}$ and its spectacular expansion, especially of higher learning proper. In this transformation, "a small, homogenous, elite and pre-professional university turned into a large,

${ }_{1}$ Political Sciences Department, Babeș-Bolyai University Cluj-Napoca, e-mail: palffy@fspac.ro.

2 The present paper does not intend to touch on theoretical issues of nationalism unless they can be related to phenomena of "nationalizing" in higher education and the effects it produces in terms of ethno-culturally based recruitment patterns. Similarly, instead of adding up further details to the already ample controversy regarding nationalizing efforts manifest in the doings of the Cluj university pre-war and inter-war situations combined, the paper intends to refine the analysis of enrolment patterns that should bring forth social dimensions of recruitment in a survey that is intended to be cross-ethnic and intra-ethnic in the same time. 
diversified, middle-class and professional system of higher learning" (Jarausch, 1983:10). First and most palpable is the up-shooting of enrolment figures, both in absolute and relative terms (that is, enrolment figures proper and these figures related to demographic backgrounds). The self-evident numerical indicator also points at the growing social importance of higher education. While quantitative expansion expressed in enrolment figures and a limited social mobility via higher educational levels did occur in Central and Eastern Europe, too, Westerntype institutional diversification and professionalization did not, the lack of them denoting a deficient modernization of the system. Besides, in their close relationship to the emerging modern nation-state, universities become key institutions not only for knowledge production but for strengthening a sense of national and cultural identity as well. (Jarausch, 1983: 11-25)

The emergence of state-engineered expanded educational systems is a crucial break in the history of education in yet another sense. "With the development of a national system ${ }^{3}$, education, for the first time, became closely connected to the state or the political system, it also changed the relationship between education and other social institutions" (Blackledge and Hunt, 1985:328). In the process of producing citizens loyal to their nation, schools in general function as major agents, central to citizen-making. In other words, they produce the emotional basis for the assimilation of a given "raison d'état", reinforcing in this way the nationalism given in the case of one or another specific state/value system (Wiggin, 1962:3-4).

Education works as an agent of nationalization: it conveys an overincreased stress on national traditions, sometimes even translated into ethnocultural values. As for Central and Eastern Europe, past conflicts tend to come down to nationalist tensions of the present. Moreover, there is often a sense of lagging behind which is seen to be mirrored in educational matters. Frustrations over backwardness ${ }^{4}$ are often compensated by an overt national awareness, a sense of belonging to a given national community, dominant or dominated. Sticking to ethno-cultural tradition helps preserve identity, while modernization is not once seen as a threat to it.

The monopolizing position of the "national language" was associated with an impartment of cultural patterns which were leading pupils and students to the acceptance of and commitment to what has been defined as national identity (Mitter, 1993: 112).

\footnotetext{
3 The reference comes from Margaret Archer Scotford.

4 The term is not meant to imply a mechanically applied East-West comparison. That the former is altogether "lagging behind" and the latter is all "advanced" would grossly oversimplify the issue of modernization itself and it would cover out enticing problem-areas of both Eastern and Western European educational developments. In other words, both areas had their specific problems as regard advancement and, instead of a clear and rigid fault-line between the two, the researcher is faced with a considerable amount of intermingling phenomena. In a similar vein, "modernization" should be perceived as having its own "deficiencies", no matter and to what extent it applies for either East or West. Besides, modernization should not be thought of in terms of a linear distribution of phases.
} 
Central and Eastern Europe has continuously been in a border-zone position well up into the 20th century. Such positioning has faced peoples of the region with perceived threats or real challenges. Survival of the ethnic community and loyalty to one's "own people" have become thus key issues (Grant, 1969: 33-35; Davies, 1993: 295-296).

Beyond economic stagnation and the lack of political dynamism, countries of the region are habitually characterized by varying degrees of social stagnation, the phenomenon being both cause and effect vis-à-vis backwardness. At least compared to Western Europe (in a somewhat generalizing perspective), most countries of the region reveal varying degrees of what may be called educational impoverishment. That is to say, educational opportunities are scarce for most, and even those existent are lacking in diversity. Thus it may be assumed that once education is but a steep and narrow path to upward mobility, its weight in social dynamics is-contrary to all expectations-even greater. Relatively few ever make for higher learning, and that in a tendentiously "national" system of education where the higher the level of formal education, the more comprehensive the involvement of the state and the higher the degree of "national affinity" the student is expected to demonstrate (Grant, 1969:45). Besides, there is hardly any sizeable democratic opening in terms of students' social extraction. As alternative study-tracks are scarce, the competition for traditional tracks is often exacerbated.

Characteristically for the whole Central and Eastern European region, the ethno-national dimension tends to overshadow any other social dimension and it also carries the day in political matters. On its turn, the political dimension tends to overrule purely social concerns or considerations. Changes of sovereignty that is, shifts in ethno-national dominance - often bring forth discontinuities if not thorough "changes of the guard" in the organization of higher learning. Ups and downs in political domination are translated into spectacular shifts in the ethnic and (to a much lesser extent and always related to 'cultural roots') social extraction of student-body, staff or, for that matter, curricula. What is more, nationalism itself goes thorough qualitative changes as we switch from empire to nation-state, not to mention the manifold consequences that this shift means in terms of higher education. ${ }^{5}$

In inter-war Romania, the nation-state paradigm reshaped the selfidentifying goals of ethnic groups, both majorities and minorities. Increased state control was also present in higher education. With a relatively low degree of

\footnotetext{
5 The "national issue" is not a novelty in the period under scrutiny. From the end of the $18^{\text {th }}$ century there have been variations of what is broadly termed nationalism here and which have played a consistent role in shaping political and educational goals. Romantic and liberal variations preceded chauvinistic nationalism, the latter of far narrower ends as regards the state-individual relationship, mirrored, among other things, in education. The end product was "totalitarian nationalism" in the $20^{\text {th }}$ century. Through it "the state swelled to such monistic proportions as to be identical with society itself. As there was no society but the national state, so there was no education but that of the citizen" (Brubacher, 1966: 61-62).
} 
autonomy, the formerly Hungarian University of Cluj was endowed with symbolic values specifically relating its fate to the main political issues of the day, often alien to strictly academic considerations. This institution (alike many in the region) was both the target and socio-cultural expression of strivings for and over symbolic domination of the ethnic communities involved.

Once an enlarged territorial framework is given, the series of measures aiming at integration and nationalization in cultural and educational affairs in the inter-war period were part and parcel of the general social revolution intended to be carried out (for reasons considered self-evident by contemporaries) along national lines. The intention to elevate the Romanian element to its "deserved" social position in Transylvania was carried out, among other things, through regional economic policies that first and most aimed at the destitution of the former (Hungarian) ruling elements on an ethnic basis.

The measures taken did alter some of Transylvania's basic social structure. The land reform redistributed large estates and while it created a Romanian smallholder class, it cut deeply at the economic bases of the Hungarian landed class. Concomitantly, the replacement of the Hungarian bureaucracy with a new Romanian one deprived the former majority of their accustomed social and political positions. To be sure, Hungarians (making up roughly a third of the population of the region to be passed under Romanian sovereignty after the war), the so-called Magyar middle class was grossly over-represented in certain segments. Public administration and justice had a 75\%, respectively 76\% Magyar presence. Combined data on the ethnic constituency of the functionaries' cluster (that is, mines, agriculture and transport taken together) reveal an even higher average, around 85\%, Magyar presence. Even in the case of notaries and lawyers, we encounter a $63 \%$ and $65 \%$ Hungarian coverage. Meanwhile Romanians, making up slightly more than a half of the population were markedly under-represented in all the mentioned categories, their share in these never exceeding a third of the one owned by Hungarians (Verdery, 1985: 72).

Yet, in a period marked by the Great Depression, it was not the creation of new white-collar jobs but the occupation of existent positions by ethnic Romanians that seemed the primary task. Economic efficiency fell at best to second place with such measures, largely directed by the Liberals of the Vechiul Regat [Old Kingdom]. ${ }^{6}$

\footnotetext{
6 "...the Liberals represent the outlook and mentality of the Regat, in which, as we said, the business life has always been in the hands of Jews or foreigners. True, they have revolted against this situation, but they have never seriously attempted to transform it. They have instead adopted a sort of glorified gangster policy, allowing the Jews to do the work while contenting themselves with a substantial rake-off. [...] The richer the Jew, the bigger the rake-off. The 'national' policy which the Liberals have applied to the minorities in Transylvania has been just the same. The 'nationalization' of the minority firms has consisted in the practice of putting in a few Roumanian directors, who are given a packet of free shares, or allowed to buy them at a nominal rate. After this, the average Roumanian director has perfectly content to fill the role of guinea-pig, his contribution to the business being to protect it against the Government. As most of these directors are Liberal politicians, they have usually been able to do so effectively" (Macartney, 1937: 324).
} 
The general outcome of such measures was advantageous for the Old Kingdom element; "Romanianization" in their way did not always mean equal gains to be registered by the Transylvanian Romanian community itself.

In order to successfully dominate, (Transylvanian) Romanians had to construct a new, majority-type identity, one that eventually overemphasized the state-ethnicity relationship. What kind of education would best suit the needs of the now dominating Romanians was a crucial issue. ${ }^{7}$ Beyond enthusiastic aspirations to modernize the inherited educational assets, in answering the question, local Romanians seem to have perpetuated the pre-war predilection for theoretical education and the largely state-managed white-collar type careerpaths opened up through it, to the disadvantage of vocational training, the private sphere of business, which would present the new ruling element with but meagre chances anyway. ${ }^{8}$ Complaints regarding the perceived "passivity" of the centralized state in defending the Romanian national capital in Transylvania were also formulated, together with warnings that if the state would not act properly in this respect, the new generations would not embrace but traditional careers, leaving the door open to "an onslaught of foreigners". The crisis of the legal profession elicited by formal centralizing measures is brought up as an example in point: it no longer figures as a real calling, it is lacking the usual material security and, worst of all, the professionals involved go through a virtual identity crisis (Livezeanu, 1995: 154, 170, 185-186, 205-207; Hitchins, 1994: 344).

An important role in the officially assumed national social revolution ${ }^{9}$ was then assumed by higher education generally, and by the Cluj University in particular. On the one hand, educational credentials were perceived as the classical means of upward social mobility, and implicitly of ethno-social redemption. More

\footnotetext{
7 The challenge is even greater if we consider the fact that over $50 \%$ of children were kept unschooled in the Old Kingdom before the war. Romanian children of Transylvania, rural areas included, were better off with regard to sheer primary school attendance (Livezeanu, 1995: 30). Nevertheless, if not confessional ones (like the five secondary schools they had at their disposal, let alone theological training itself), they tended to perceive their schools as de-nationalizing agents. In addition, secondary schooling was by far not as generous with Romanians as the primary one. Gains in social position via education were possible only by a certain amount of "Magyarization." That is to say, the upwardly mobile non-Hungarian clusters tended to be faced with the need to formally integrate themselves into the "dominant Hungarian element."

${ }^{8}$ In the long run even white-collar job-openings - part of which appeared through the dismissal of non-Romanians from such posts - proved to be of a limited number. Soon the new Romanian academically trained elite faced unemployment or under-employment.

${ }^{9}$ With all the optimistic (and poorly-grounded) boom in the short run, Greater Romania - just like many other countries of the region - seems to have experienced rather a failure in the long run: nationalising assets did not "revolutionize" and could not solve age-old problems by itself, and the ensuing frustrations prepared an easy way for Right-wing orientations. Even some of those who propose to analyze academic changes in line with social challenges tend to put aside the latter in favour of depicting nationalizing efforts, somewhat mistaken for the modernizing strife (Pușcaș, 1995: 165-170).
} 
university graduates meant a greater degree of embourgeoisement, something that the Transylvanian Romanian community did indeed need otherwise. Generally, enrolment figures became one of the chief preoccupations in inter-war Romanian higher education. To be sure, the concern for more graduates soon changed into worries about too many enrollers.

The ensuing rapid growth in student population nationwide already in the 1920s resulted in overcrowding, bad ratio of completion of studies, let alone general frustration, distemper and uncertainty among the educated elite. Between 1914 and 1939, the population of Romania doubled, but the number of the students quadrupled. That alone was neither unique, nor represented the problem in itself. It was the general lagging behind and the lack of consistent modernization and/or diversification of available study-paths that compelled most to perceive state-managed jobs as the only feasible and profitable path that they supposed they were entitled to exactly via higher learning.

\section{Law students of the Cluj University}

A sizeable student body nevertheless figured as an important piece of symbolic capital in the minds of political leaders and academic staff alike, let alone the immediate practical result that it implied, that is, producing state officials and trained personnel out of the midst of the ethnic Romanian population of the new province. The flocking of ethnic Romanian candidates to the university (for a while the number of Hungarians candidates was decreased by the severe Matura examination conducted in Romanian beginning with 1925) was only halted in 1934, when harsh measures were adopted to filter the would-be trained elite by way of an entrance examination. Even this attempt to keep enrolment figures under control produced no palpable results except in the case of ethnic minority students, but it failed in the longer run with Romanians themselves.

In his 1939 inaugural speech, rector Ștefănescu-Goangă still voiced the same worries concerning overcrowding as his predecessor, Sextil Pusccariu two decades ago. The rector's criticism went against the lack of selection, which made the serious, laborious students a minority among the student body. Instead, the majority was, especially in the thirties, almost permanently engaged in political rallies, anti-Semitic moves, strikes and scandals. Big rallies - in 1923, 1928, 1933, and 1938-39 - proved to be an almost regular occurrence.

Meanwhile, the ratio of completion of studies (a prominent indication regarding the profitability of "investment" in higher education) depended on the chosen track: the least successful were those enrolled in law, only $8 \%$ ever managing to finish their studies nation-wide, while those in letters and philosophy seem to have done best in this regard, an average of $28 \%$ completing their studies successfully (the nation-wide average of completion of studies was one success to 
nine failures, the worst in that period in all Europe). Faculty-to-student ratios went somewhat the same way: it was the worst at the law faculties (in average $1 / 121)$, medium in theology $(1 / 55), 1 / 34$ in letters, with $1 / 32$ as the best for the period registered in the pharmacology department. As for universities, it was in Iași that this latter ratio was the worst nation-wide, and even further worsening in the 1930s (Livezeanu, 1995: 212-216, 235-236).

With all the initial optimism and the aspirations to modernize the Romanian university in Cluj, not much could be done in the long run in this respect. After all, it could have hardly been a feasible project to create an independent, de-politicized scientific workshop in the Western style in Cluj, combining the German and American models, going in parallel with the markedly French traditions and the political involvement manifested by Old Kingdom universities. In vain Rector Sextil Pușcariu (himself coming from the University of Iași) made it evident early in 1920 that the import of such traditions into the newly acquired universities (Cluj and Cernăuți, which by and large followed the German model until the takeover) would create tensions and frustrations on both sides of the Carpathians (Pușcaș, 1995: 122,132). Beyond turning the university into a state-agency of nationalizing and a workshop of national eliteformation, not much seems to have been done in terms of the social dimensions that the university student body either depended on or created itself. Even the inherited academic structure, intra-departmental distribution and curricula went basically unchanged

All the while law studies were the most popular and populated, swelling the ranks of university students to a far greater extent than any other study track in the periods. It may well be assumed that at the universities of Budapest, Cluj/ Kolozsvár, Bucharest and Iași taken together, about half of the students chose law, at any rate, almost as many as all the other specializations added together. The trend prevails in the inter-war decades: of the over 30,000 students registered in 1928-1929, 38\% were in law, around one quarter of the total in letters, less than a fifth in natural sciences, even fewer in veterinary medicine, pharmacology and theology $-7 \%, 5 \%$ and $4 \%$, respectively. Those opting for medicine were of a mere $1 \%$ of the total. As a study-track that did not seem to require full-time attendance, law was the most popular among those seeking state-employment: of the 17,779 degrees produced by Romanian universities in a ten-years' period ranging from $1021 / 22$ to $1931 / 32,43 \%$ were in law, compared to $29 \%$ in letters and philosophy, $16 \%$ in natural sciences and mathematics, for instance. (Livezeanu, 1995: 212-215)

The University of Cluj, as a whole, is not an exceptional case in the context of inter-war Romanian higher education and Transylvanian universities, especially in terms of its size, composition and the orientation of its law student contingent. Rather, it is the similarities that seem deceptive for some of the (early) Cluj university leaders, while others sought an even greater similarity with Old Kingdom 
patterns. The law faculty recruitment patterns are particularly analogical with those of Iași, the other full-structured provincial university of greater Romania. Nor is the law student contingent or the (inter-departmental) recruitment patterns characteristic to it a novelty as such or a product of Romanian sovereignty: In the pre-war era, the at the time Hungarian university of Transylvania hosted an equally over-sized law department, one which put ethnic minorities in a quantitative disadvantage against a pronounced over-representation of the (ethnically defined) majority (Pálfy, 2005: 203-212; 93-97).

The statistical survey ${ }^{10}$ to which we make reference in this paper encompasses the 1918-1948 period. While in several instances we encounter lacunae in Matricolas of other departments, documents of this type referring to the law faculty are at our disposal in integrity. The whole contingent numbers 12,624 law students. The yearly distribution along the time-span is surprisingly even: we have 4,712 students for the first decade, that is, 1918-1929, 4,935 for the 1930-1943 period (including the war years, when the Cluj Romanian university took exile to Sibiu), and 2,977 registered students between 1943-1948 (a contingent in which war-time decrease is somewhat compensated for by the presence of law students at the parallel Hungarian university in Cluj (the Bolyai University, founded in 1946).

While we focus on the thirties, we have to bear in mind that the phenomena, patterns and tendencies of enrolment may gain their full meaning only if compared to those encountered with the whole surveyed period and to those seen in the case of other departments. As for the rest of law students, the evenness of yearly numerical distribution is paralleled by a steadiness of distribution along meaningful variables, especially if we think of the 1920s. No dramatic shifts seem to have occurred in the size or composition of the student body of the now Romanian university. Owing to the lacunae encountered with other departments in enrolment lists, a full-fledged comparison to these would hardly be possible. With all these backtracks, the main variables according to which we intend to sketch the internal distribution of the focus-contingent, that is, age, region of birth, gender and ethno-cultural belonging can, even if somewhat indirectly, meaningfully describe the targeted group in terms that, we hope, can help trace the social history of the Cluj university with regard to enrolment patterns, career orientations, academic success, employment perspectives, both inter-ethnically and intra-ethnically. The forthcoming description relies heavily on quantified data. Figures are seldom telling by themselves. It is the correlations

\footnotetext{
10 The comprehensive research, of which the data hereby used are only a small section of, encompassed elite-formation mechanisms and phenomena throughout Central Europe in the period between 1850 and 1950 and was carried out by a team coordinated by Professor Viktor Karády from Central European University. These are the first partial results that the author puts forward, nevertheless avoiding the table-format which contains a set and combination of data on enrolled students at the university of Cluj in the targeted period going much beyond the scope of the present paper in sophistication.
} 
between and combination of the figures that make conclusions possible. All being said, the following is only a selection of such correlations, without the intention of enlisting all the possible details.

If we track the age variable ${ }^{11}$ in different combinations with the other variables, a number of conclusions become possible regarding the student body. Correlated data of age of graduation and region of earning one's Matura/Baccalaureate (that is, where available) show that one third of the 1930s law student contingent got their Matura in Southern Transylvania (where there were more ethnic Romanians, the region also including the great majority of the Saxons as well), one third came from Partium and Banat, the remaining from Northern Transylvanian high-schools. The contingent earning their diploma at the earliest estimated possible age is of an average of $43 \%$ in each regional category, with irrelevant differences among the regions. Another indirect age-marker is date of birth. The bulk were of course born between 1910 and $1919(3,461)$, about one fifth $(1,034)$ in the previous decade, and very few, only around every twenty-fifth enroller, were born after 1920, with the same small size of the group born before 1899 .

Of the 1,587 students having this data registered, more than three quarters earned their Matura between 1929 and 1935, with none of the previous academic years exceeding a yearly average of 10 enrollers. The post- 1935 period presents a yearly average of 70 newcomers. Interest in law studies seems to have shrunk considerably after 1935. That is so even we consider that the Oradea Law Academy was melted into the Cluj Law Faculty in 1932 (meaning an additional transfer of around 1,000 students at the outset).

By age of Matura-earning (data registered with 3,339 students out of the total of 4,935 in this temporal cluster), 64.5\% earned this degree at or before 19 , the rest were of twenty or older. In other words, only half of the registered contingent got their Matura at the age considered as desirable or "normal" (around 18), the delay with the remaining half also accounting for later enrolment and later completion of studies. We may presume that those less successful in academic terms add up delays in high school and university. With only one out of five graduating from high school after the age of 20 , we may also presume that prolonging university studies can account for the bigger part of the delay.

As of age of enrolment, (with only 12 missing from the contingent of 4,935 , the absolute majority came to the department at ages between 17 and 25, ages 18, 19 and 20 being over 500 in absolute figures, 17 years old early beginners being about 400 (one out of twelve) in number. Latecomers are few, with the latter age contingent - those 26 to 30 years in age - accounting for around 100 enrollers.

\footnotetext{
11 This variable is commonly considered as highly relevant for the degree of success attained in studies, a qualitative marker to be considered both inter- and intra-ethnically. This is why this variable appears in most of the mentioned combinations.
} 
In order to determine students' ethnic extraction, family names are also employed. To be sure, ethnic character of family name alone is prone to bias and misinterpretation, as certain fractions of linguistically Romanian names may hide non-Romanians, for instance. Moreover, ethnic identity as such is much more complex, also involving mother tongue, religious belonging, family relations, being ultimately an issue of self-identification. With all the limitations, it seems purposeful to make use family names as one of the indicators of one's most likely ethnic affiliation, in a combination with other indicators when possible.

Age of enrolment referred to ethnic character of family name presents the following distributions: inter-ethnically, those bearing a Romanian name have a relative majority, 2,421 in absolute numbers. They are followed much from behind by 1,122 Hungarians by name, 692 Germans and 688 "other". In the case of Romanians, $17.5 \%$ were enrolled before or at the age of 18 , another $25.2 \%$ up to the age of 20 (included). Every fourth Romanian student enrolled at the age of 26 or later, $17.6 \%$ going to university after the age of 22 . The latter two clusters combined make that four out of ten Romanian students were belated enrollers. As for those with Hungarian names: as many as $34.6 \%$ enrolled at an age younger than 20 , a somewhat worse ratio as with the Romanians. In the same way, the late-comer part is just a little bit larger than with the previous group. $36 \%$ of those belonging to the German-sounding name cluster begin their studies at a normal age, with about the same amount of late-comers. It seems that it is them who begin relatively early. The question is whether they end their studies in due time or not. It seems plausible that Hungarians take a longer time to take their Matura, but once they have it, they are not prone to prolong university studies. Still, they are near not so fast, that is, successful in academic pursues than Germans and, especially and rather expectedly, Jews.

Ethnic background indicators put forward another issue: a massive numerical dominance of the student contingent cluster registered by Romanians, something which comes up several times in the other combination of variables. As a remarkable feat, Romanians literally reversed the order to their advantage as regards ethnic composition. Before the war, the then majority Hungarians made up around $80 \%$ of the whole student body, with Romanians being grossly underrepresented. Shortly after the war, it is Romanians who make up more than $70 \%$ of the students, with minority Hungarians losing most of their positions. Other non-majority groups like Jews and Germans seem to have maintained their numerical representation and intra-ethnic social selection standards, pre-war and inter-war situations combined (Pálfy, 2005: 97-112). As regards the oftenquoted losses encountered by the ethnic Hungarian community in terms of elite-production, one should not forget that comparing their inter-war situation to the pre-war one is at least misleading: for evident reasons, they were unnaturally 
over-represented while they were a political majority within the academicallybased elite (the size of which elicited worries among Hungarians themselves in the pre-war decades).

Even though the age of enrolment according to declared native tongue can be followed only with around half of the basic cluster, the ratio of early beginners seems highest with Hungarians and Germans by native tongue, medium with the "other" category (very small in absolute figures, though), while Romanians present a relatively even distribution among the age-categories, yet they seem to be prone to begin studies at a later average age than Hungarians/Germans.

This phenomenon is mirrored by another combination of variables as well. Enrolment according to region of birth shows that those coming from Romania proper, 244 in number are older when they enrol than those from any other region. While only $18 \%$ of them enrol under the age of $20,41 \%$ enrol very late, at or after the age of 26 , while an additional $17.2 \%$ enrol at ages between 23 and 25, making two out of three arrive at Cluj as late beginners.

Those 2,429 born in Transylvania are relatively the youngest: a little more than one third is to be found in the first, early beginner age category, with a little less than one third in the late beginner category. With 1,376 students, those born in Banat and Partium are in between the former two. Hungary (not once the term denotes former Hungarian territories) and "other" as place of birth are but a mere 193 and 42, respectively, yet even these two locations seem to have sent students of law to Cluj at an earlier age than that of those born in Romania (that is, the Old Kingdom). Beyond considerations of age, this territorial distribution is very much telling in another respect: the pool of recruitment of the Cluj Law Faculty remained an overwhelmingly local one. Few were coming from outside of the newly acquired Western territories (that is, Transylvania proper together with Banat and Partium), foreign citizens were very rare exceptions. All put together, the number of those born elsewhere never exceeds one tenth of the total of 2,429 with a registered birthplace.

Geographical proximity in general and being situated in urban areas in particular seem to offer advantages, irrespective of ethnic background. Besides, while there was a considerable effort made to compensate for the pre-war underrepresentation of ethnic Romanians among Transylvanian town-dwellers, in the latter part of the inter-war period there was still a relative over-representation of Hungarians, Jews and Germans in urban areas. Having in view the social and economic circumstances, it is very likely that both those beginning and graduating university at an early age came from the towns rather than from rural areas, even towns from outside of the region.

If we relate age of enrolment to confession, we encounter a pattern highly similar to the ones seen in the pre-war age: Israelites are the youngest relative enrollers, together with Evangelicals. Protestants follow suit, while 
Roman Catholics and those of the two Romanian faiths -Greek Catholics and Orthodox - present (much in the same order) the oldest relative cluster of enrollers.

Regarding the year of completion of studies, we have a total of 2,406 cases when completion (or termination or halting them at an advanced stage) of studies is ever registered. The peak years were 1935, 1936, 1937, 1938 and 1943, when a little over 300 students received some kind of degree, on average. The late mid-thirties produce the bulk of diploma-owners, since this was the other end of the wave of enrolment encountered approximately fourfive years earlier. The leap from 1938 to 1943 is due to war-time conjecture, just as 1943 as a top-year of diploma issuing at the law department is related to the shifts in political dominance occurred in the early forties.

If we relate age of completion of studies to confession of graduates, we encounter some unexpected, yet rather small differences. Of the 136 Roman Catholics, $34.6 \%$ graduate at or before 23 and $38.2 \%$ after 25. The 91 Calvinists are distributed roughly in the same manner as regards intra-confessional age clusters. The 42 Israelites prove to be the earliest and youngest degree-owners, Evangelicals following only very slightly behind. Beyond these seemingly usual patterns, we have those of the "other" confessional category, where the absolute majority is made up of Orthodox and Greek Catholic students, who were overwhelmingly Romanian. Out of the 1,084 students listed in these confessional groups, $30.0 \%$ graduated before or at the age of 23 , thus slightly fewer than the percentage for the other confessions, embraced mostly by Hungarians, Jews and Germans. Correspondingly, slightly more, i.e. $46.9 \%$ ended their studies after the age of 25. Put otherwise, roughly two thirds of Romanians were able to obtain the degree only at the price of prolonging their studies.

A more refined intra-ethnic analysis, one contrasting Greek Catholic and Orthodox Romanian law students would be very interesting, yet it is not available so far. Studies encompassing the pre-war era (more precisely, medical students of the Cluj University), nevertheless demonstrate that, in general, Greek Catholic Romanians were the more prone to choose lay career paths that better integrated them into the (by then Hungarian) majority society; by that time Greek Catholic Romanians manifested a slightly more pronounced general inclination towards embourgeoisement than their Orthodox Transylvanian co-nationals (Karády and Nastasă, 2004: 91-99). They seemed slightly more open for lay careers as such than their Orthodox co-nationals, even exceeded them in terms of academic success measured as ages of enrolment or graduation (although Greek Catholics were still exceeded in this latter regard by all the other confessions, embraced mostly by other ethnic groups).

Again, if we relate age of graduation to region of birth of students, we have those from the Old Kingdom graduating with a considerable delay, two out of three finishing at or after the age of 26 , while only roughly 1 out of 3 Transylvanian- 
born graduates (all confessions or ethnic groups included) are "old" when they graduate. Transylvanian Romanians tend to graduate earlier than their Old Kingdom colleagues while non-Romanian Transylvanians (especially Jews and Germans) have a slight advantage even over Romanians coming from the newly acquired Western territories. Nevertheless, this set of data has considerable parts missing, the cross-tabulation being possible only for a little less than half of all the registered cases.

According to age and declared native tongue we get the following split: of the 164 Hungarians, only one out of four did not graduate at or before 25 , in other words, having only one out of four to be a late graduate is a remarkable feat under the circumstances. Of the 61 Germans by native tongue only six (only every tenth) graduated in the "late" category. Romanians are but slightly 'older' than Hungarians when graduating: of the 435, 74,6 \% graduated at or before 25, the remaining one quarter after that. As for the other mentioned ethnic marker, family name, we have an almost even distribution of age-categories, both inter- and intra-ethnically. All non-age clusters taken together, very few graduate before the age of $22(7,4 \%)$, the bulk, every second law student, earn their degree between the age of 22 and 27, to be considered the characteristic graduation age-cluster with law students, a somewhat higher age than what one could expect generally or in comparison to other departments. In addition, every fifth of the law students graduated at a pronouncedly advanced age, that is, between 27 and 33, the remaining are special cases, especially the $5 \%$ earning their degree after 39 years of age.

Last but not least, the age variable can be related to the gender variable. Out of the 4,923 cases listed, 863 men enrolled at the earliest possible age, 551 around a year later (together: around $32 \%$ ), while a massive figure (roughly $50 \%$ ) of the men enrolled with several years' delay (at the age of 23 and later, 1,996 male students). In the case of women, the female group totalling 444 enrolled, age ratios are the other way round: almost half had the early graduation age, less than $20 \%$ were recorded in the late enrolment cluster. On average, women tended to enrol at an earlier age, and they were less prone to enrol at a late age. As for the status of the female law student, it is telling that only every eleventh student was a woman, the law department, the least "feminized" of all, being perhaps the most conservative in this regard as well. Other departments seem more open as regards female enrollers, while the law track looked most rewarding for the conservative-minded segment of the would-be learned elite.

If we take a look at the cross-tabulation containing gender and confession, it is somewhat surprising that the Roman Catholic and Protestant contingents included the smallest intra-confessional percentage of women, followed by the two "Romanian faiths" at a considerable distance to the advantage of women against the less than one percent with the first two confessional clusters, these latter two accumulated an average of over $6 \%$ female students in the intra- 
confessional combination. The Evangelical female student share is even better, if only expressed in percentage, and, not at all surprisingly, we find 47 women and 208 men among the Israelite contingent, almost every fifth of this cluster being women. Against all odds, Jews, although less over-represented than before, are once again the relatively most successful in their studies and most versatile in options. Similarly, we have 247 women among the 2,286 considered as graduated, that is to say, female students were not lost on the way, their share among diploma-owners even increasing, thinly but visibly (that is, if compared to their representation on the undergraduate level). Put otherwise, women had higher probability to eventually graduate, as compared to men.

It is remarkable that neither the gender, nor the ethnic distribution of law students changed significantly from the 1920s to the 1930s. In a similar vein, territorial belonging of students, as indicated by the place of Matura-granting school, registered in 3,093 cases presents a rather even distribution of students territorially: Partium and Banat gave 29.9\%, Northern Transylvania 35.4\%, Southern Transylvania $34.4 \%$. Amazingly few students earned their Matura elsewhere, yet another indicator of the markedly local demand that the Cluj law faculty answered throughout the inter-war period, even if we take territorial distribution as place of birth: the virtually complete contingent for the thirties has $46.1 \%$ born in Transylvania, 29.6 in Partium and Banat, 7.5\% in Hungary, $14.9 \%$ in Romania, with an infinitely small number registered as born "elsewhere".

Interestingly enough, in the official discourse of university leaders the relative degree of tolerance demonstrated vis-a-vis non-Romanians (basically meaning Hungarians and Jews)or, for that matter, women worked as a basis for boasting the open and democratic character of the Cluj university in the twenties. Yet by the mid-thirties the enrolment figures demonstrating a sizeable ethnic minority presence (Jews being the main concern this time) were eagerly re-interpreted as a chief worry and as threatening the positions of the Romanian element.

\section{Concluding remarks}

The enrolment patterns, size and internal distribution along relevant variables met with the Cluj law student contingent of the thirties are the result of state-sponsored ethnic competition within a non-diversified market: with little room for alternative professional clusters, would-be educated elites have to accommodate with traditional paths of upward social mobility, among which law is the main segment, a study-track that went through a veritable reethnicization. Enrolment ratios according to ethnic background are altogether reversed, Romanians quickly gain the upper hand, Hungarians encounter severe setbacks, while Jews and Germans seem to have maintained pre-war standards and by and large produced patterns that characterized these ethnic clusters 
before the war as well. It is notable that while political sponsorship on ethnic grounds produced significant quantitative results in the case of the now majority Romanians, many of the qualitative aspects - curricula and the "inherited" so-called traditional study-tracks not allowing for new departments - were pretty much resembling those encountered with ethnic Romanians before. Notwithstanding their small numbers among the students, it was Jews and Germans that fared relatively best in terms of academic success, followed by Hungarians, while Romanians on average did not manage to live up to the great expectations of the early twenties. To be sure, the undertaken nationalizing efforts could not have so thoroughly and so quickly changed the socio-historical and ethno-cultural backgrounds from which Romanians came from.

The main target of the Romanian "cultural offensive" launched by the Liberal Party based in Vechiul Regat [the Old Kingdom] was to unify Romanians as a nation via getting rid of regional boundaries and enhancing the positions of Romanians in general. Social boundaries or the situation of the peasantry, by far the most numerous layer of society, were not among the main preoccupations. Not once in educational matters, the expansion that the strife for "cultural offensive" meant in practice entailed dilution, that is, a set-back to quality. The long-term result of unifying nationalization was the overall politicization of the academic sphere (Livezeanu, 1995: 35, 37).

The consequences were to be felt in university finances, the eligibility criteria of academic staff, students' guided career-choices and the perspectives of a professional career. It was in the thirties that anti-Semitic and xenophobic drives came to full dimensions and their consequences unfolded: repeated attempts to remove the "alien" element, especially Jews, but Hungarians as well, to the intended advantage of the "autochthonous element" (that is, native Romanians) both in the academic sphere proper and in the overall setup of the white-collar job-market depending on academic qualifications.

It did not seem to have occurred to the concerned officials that merely reversing ethnic domination directions while going on with pre-war enrolment and career-choice patterns would eventually reproduce the structural deficiencies met with that pattern. Once again modernization and social emancipation is mistaken for a sheer numerical boom, a quantitative leap clearly putting forward the need of the Romanian element to "modernize" its class-structure (otherwise an evident and normal need in the changing economic context), that is, raise a considerable middle-class layer using time-honoured academic grounds, law studies par excellence. Malfunctions and redundancies were imbedded in the (re)produced scheme, while the other way, modernizing society via modernizing higher learning (introducing new study-track, like polytechnic education) proved to be a hardly feasible project under the circumstances of state-engineered nation-building integration efforts that carried the day in the period. To be sure, neither Hungarians nor Romanians seemed to be prone to intra-ethnic social dynamism. 
While the first produced some degree of retrenchment via law studies, the latter could witness some democratic opening limited, to be sure, to the first generation of students, of this or the other study-tracks, so much desired otherwise in the theory of the envisaged national revolution.

Generally, for the first three decades of the 20th century, career-choices were not strategic in the sense that they closely followed the ephemeral tides of conjuncture. The job-market was dominated by the state in such a manner that made any other alternative limited in scope, if not altogether unrealistic. ${ }^{12}$ Diplomas were assumed to assure a better living standard, and higher educational credentials were considered to override lower academic qualifications. The inflation of educational credentials resulted in qualitative unemployment. Once those with Matura were pushed out from the job market by those holding a postsecondary degree, and the latter, in their turn, were pushed out by university graduates, the only chance that the educated had to earn a living was to accept positions even considerably lower than what their degrees would have normally entitled them for. ${ }^{13}$ Beyond the imminent threat of social decay, this led to further distress and frustration, ultimately channelled into xenophobic drives.

Law is traditionally and with a conspicuous notoriety one of the most popular (if not the most popular) and most populated study-tracks. While it seems to involve a relatively low level of investment in terms of intellectual innovation or technical support (it is a "cheap" study-track and degree, compared, for instance, with medical studies) this is the "gentlemanly department" allowing pursuers formal social elevation or the maintaining of such positions. ${ }^{14}$ Dependence on the characteristically state-administered job-market makes the attained social

12 The decline in the interest on the part of industrialist to employ academically trained personnel may be accounted for by the fact that these were usually elitist and over-politicised. Anyway, industry and public utilities offered the academically trained only a fraction of the entries they reserved for non-academic white collar personnel in the 1920s (Kovács, 1994: 73). While presenting a much similar setup, inter-war Romania job-assignment mechanisms often denied a priority of non-professional considerations, political and other types of clientelism, for instance.

13 Contemporary Hungarian statistics and sociological research was rather keen on this issue. (Kornis, 1934: 2, 33; Laky, 1931a: 35; Laky, 1931b: 43 - 47)

14 There is a considerable resemblance with the by now destitute Transylvanian Hungarian middle class. The class-character of the Hungarian state bureaucracy (by which prevalent social roots the Magyar civil service employees were not quite alone in the region) also functioned as a model of social status and ascendancy for two other social groups related to it: the learned elites and the urban, more capitalist-oriented middle stratum, a good part of which were affiliated by specific goals and mentality to the 'gentlemanly' wage-earners. With them, office and job were evaluated according to their status in society and to how close this status was to the historic one of the nobility. The prevalent view was that (in contrast to the lower status associated to the entrepreneurial and free professional class) the career of the intellectual class could attain its full "gentlemanly" dimension only if it was rooted in the hierarchy of state-employed officials and service elites. The social value of the learned professions was not so much inherent in their professionalism, that is, making specialized knowledge operational, but in the position they were entitled in the state-bureaucracy (Erdei, 1981: 203-219). 
position (reached through academic credentials) to be itself dependant on the state, not to mention political issues of the day. The anomaly - a stateorchestrated "middle class" - makes for over-emphasized loyalty, assuming the "proper" political orientation. It ultimately pushes sheer professional considerations into the background, while the ethnic dimension overshadows the social one.

Except for ephemeral intermezzos, the "revolutions" that occurred in this part of Central and Eastern Europe were not social but national in essence, a feature of defective modernity directly reflected in (if not induced by) malfunctions of the educational system. Ethnic competition is exacerbated and taken for structural improvement. Needless to say, modernization is a totally alien perspective anyway, if not a direct threat to national identity, for autochthonist ideologues who regard ethno-national self-containment and self-preservation as basic concepts. Embedded in this perception is the recurrent tendency to diminish the role of intra-group social selection and effective promotion on meritocratic, professional or, least of all, market-oriented grounds. Meanwhile, in the face of a perceived historic challenge, neither state nor nation would ever hear of assimilation as a means of integration. The state-forming majority was to be integrated instead, exclusionary drives and dissimilation being considered as natural, lawful and self-evident strategies. In the form many of inter-war state-nations sought it, selfintegration tended to imply rightist political radicalization. It is by no coincidence that the numerus clausus law in Hungary or the Iron Guard movement in Romania had student political distemper at their starting-point. In both cases, radicalization follows a usual path, social and professional dissatisfactions are easily translated into political extremism. In the process of elite-formation carried out via the expansion of the category of those with higher degrees, academic or professional considerations tended to slip into the second place.

\section{REFERENCES}

Blackledge, D. and Barry H. (1985). Sociological interpretations of education. London: Croon Helm.

Brubacher, J. S. (1966). A History of the Problems of Education. New York: Mac GrawHill Book Company.

Davies, C. (1993). Concentric, Overlapping and Competing Loyalties and Identities: Implications for education. In K. Schleicher (ed.): Nationalism in Education. Frankfurt: Peter Lang, pp. 295-328.

Erdei, F. (1981). A magyar társadalom a két világháború között [The Hungarian Society between the Two World Wars]. In T. Huszár (ed.): Értelmiségszociológiai írások Magyarországon 1900-1914 [Writings on the Sociology of Intellectuals in Hungary 1900-1914). Budapest: Kossuth. 
Grant, N. (1969). Society, Schools and Progress in Eastern Europe. Oxford: Pergamon Press. Hitchins, K. (1994). Rumania, 1860-1947. Oxford: Clarendon Press.

Jarausch, K. (1983). Higher education and social change: Some comparative perspectives. In K. Jarausch (ed.): The Transformation of Higher Learning 1860-1930: Expansion, diversification, social opening, and professionalization in England, Germany, Russia and the U. S. Chicago: The University of Chicago Press.

Karády, V. and Nastasă, L. (2004). The University of Kolozsvár/Cluj and the Students of the Medical Faculty (1892-1918]. Budapest/Cluj-Napoca: Central European University Press and the Ethnocultural Diversity Resource Center.

Kornis, G. (1931). A szellemi munka válsága [The Crisis of Intellectual Work]. In G. Kornis (ed.) Az értelmiség válsága [The Crisis of the Intellectuals]. Budapest: Franklin.

Kovács, M. M. (1994). Liberal Professions and Illiberal Politics: Hungary from the Habsburgs to the Holocaust. New York: Oxford University Press.

Laky, D. (1931a). Az értelmiség válságának szociális és gazdasági háttere [The social and economic context of the crisis of the intellectuals]. In G.Kornis (ed.): $A z$ értelmiség válsága [The Crisis of the Intellectuals]. Budapest: Franklin.

Laky, D. (1931b). A magyar egyetemi hallgatók statisztikája 1930. Magyar Statisztikai Közlemények, n. s. vol. 87.

Livezeanu, I. (1995). Cultural Politics in Greater Romania: Regionalism, Nation-Building and Ethnic Struggle, 1918-1930. London: Cornell University Press.

Macartney, A. C. (1937). Hungary and her Successors: The Treaty of Trianon and Consequences 1917-1919-1937. London-New York-Toronto: Oxford University Press.

Mitter, W. (1993). Nationalism, regionalism and internationalism in Europe: An eastwest comparison of educational development. In K. Schleicher (ed.): Nationalism in Education. Frankfurt: Peter Lang, pp. 107-131.

Verdery, C. (1985). The Unmaking of an Ethnic Collectivity: Transylvania's Germans. American Ethnologist, 12(1): 62-83.

Pálffy, Z. (2005). National Controversy in the Transylvanian Academe: The Cluj/Kolozsvár University in the First Half of the 20th Century. Budapest: Akadémiai Kiadó.

Pușcaș, V. (1995). Universitate, societate, modernizare. Organizarea și activitatea științifică a Universității din Cluj, 1919-1940 [University, society, modernization. The organization and scientific activity of the University of Cluj, 1919-1940]. Cluj-Napoca: Presa Universitară Clujeană.

Wiggin, G. (1962). Education and Nationalism: A historical interpretation of American education. New York: Mac Graw-Hill. 